\title{
Effects of fixation and enzymatic digestion on the immunohistochemical demonstration of laminin and fibronectin in paraffin embedded tissue
}

\author{
P KIRKPATRICK, AJ D' ARDENNE \\ From the Department of Pathology, John Radcliffe Hospital, Headington, Oxford
}

SUMMARY The effects of different fixatives and enzymatic digestion procedures on the immunohistochemical demonstration of fibronectin and laminin in paraffin embedded tissues have been compared. None of the fixatives tested enabled staining of these proteins without enzymatic digestion. No intracytoplasmic laminin was found either in fixed or in fresh frozen tissue. Fixation in formol acetic acid was unsatisfactory for demonstration of fibronectin; prolonged fixation in formol sublimate was unsatisfactory for demonstration of laminin. Optimal results were achieved after fixation in routine $10 \%$ formol saline. Trypsin was completely ineffective for unmasking laminin antigens except after fixation in ethanol acetic acid; it was only partially effective for showing fibronectin antigens. The best results were obtained with protease digestion, but pepsin was an adequate, although slightly less reliable, alternative. These enzymes may be used at lower concentrations than usually recommended.

Fibronectin and laminin are non-collagenous connective tissue glycoproteins in which there is currently much interest. ${ }^{1-5}$ In normal tissue laminin is present in basal lamina of epithelial, endothelial, and mesenchymal cells. ${ }^{3}$ Fibronectin is found in association with both basement membranes and interstitial connective tissue. ${ }^{67} \mathrm{~A}$ soluble form is present in plasma and extracellular fluids. ${ }^{1}$ Recent studies have suggested that immunohistochemical demonstration of these proteins may be of value in diagnostic pathology. Possible applications include diagnosis of soft tissue tumours ${ }^{58}$ and diagnosis of adenoid cystic carcinomas of breast (d'Ardenne et al, unpublished observations). If such staining is to be useful it is vital that the methods used are both convenient and reliable. The purpose of this investigation was to compare different methods most applicable for use in a routine diagnostic laboratory and determine factors which may give rise to false negative or positive results.

Ideally, all immunohistochemical staining should be performed on fresh frozen tissue, but often this is not available unless its requirement is anticipated in advance. Furthermore, the resolution obtainable with fresh tissue may be inferior to that obtainable with fixed tissue.? An alternative is to use a fixative and embedding procedure which does not affect the antigens under investigation. Positive staining for fibronectin and laminin has been reported after fixation in ethanol acetic acid at $4^{\circ} \mathrm{C}$ and paraffin embedding, ${ }^{49}$ but only intracytoplasmic laminin was shown. Laminin in basal lamina was not shown without subsequent trypsin digestion. ${ }^{4}$ In another study none of a variety of fixatives, including ethanol acetic acid, was found satisfactory for retaining fibronectin antigenicity in paraffin embedded tissues without enzymatic digestion. ${ }^{10}$ The effects of formol sublimate and of $10 \%$ formol saline with $2 \%$ acetic acid, fixatives which have been recommended for immunohistochemical staining of cytoplasmic immunoglobulins, ${ }^{11} 12$ have not yet been investigated for fibronectin and laminin.

There have been several confirmations ${ }^{910}$ of the original observation that pepsin digestion can be used for unmasking fibronectin antigens in formalin fixed tissue, ${ }^{13}$ although the recommended pepsin concentrations have differed. ${ }^{10}$ Protease has been found equally effective ${ }^{14}$ and the method has also proved applicable to laminin demonstration. ${ }^{15}$ Trypsin has been found unsatisfactory for fibronectin staining by some authors, ${ }^{9}$ but this has not been the experience of others. ${ }^{8}$

Since it may be advantageous to know the distribution of both fibronectin and laminin in a par- 
ticular specimen, the effects of different fixatives, fixation times, and enzymatic digestion techniques on demonstration of both proteins have been compared. Fixatives which have been studied previously and which appear to confer no particular advantage on fibronectin staining have been omitted from the investigation. ${ }^{10}$ These include Bouin's fixative, Clarke's fixative, Lillie's acetic-alcohol-formalin, and graded ethanols. The four fixatives chosen for study were routine $10 \%$ formol saline, formol acetic acid, formol sublimate, and ethanol acetic acid at $4^{\circ} \mathrm{C}$. In the first part of the investigation enzymes were used in the standard recommended procedures on tissue which had undergone variable fixation. In the second part the enzymatic digestion protocol was varied while fixation was kept constant. This was done partly to determine if the standard enzyme concentrations and digestion times could be reduced, thereby minimising laboratory expenditure.

\section{Material and methods}

Fresh human breast tissue was obtained from a mastectomy specimen and representative blocks measuring roughly $1 \times 0.5 \times 0.5 \mathrm{~cm}$ were taken of both normal tissue and carcinoma. These were fixed for 12,24 , and $48 \mathrm{~h}$ in each of the following four fixatives:

$110 \%$ formol saline (unbuffered)-routine fixative

2 Acetic acid-formol saline ( $10 \%$ formol saline plus $2 \%$ acetic acid) ${ }^{12}$

3 Formol sublimate (10 parts formol saline plus 90 parts saturated aqueous mecuric chloride $)^{1112}$

4 Ethanol acetic acid (99 parts $95 \%$ ethanol, 1 part glacial acetic acid) used at $4^{\circ} \mathrm{C} .^{49}$

All specimens were processed routinely using a $17 \mathrm{~h}$ automatic processing schedule comprising $8 \mathrm{~h}$ in industrial methylated spirit at $20^{\circ} \mathrm{C}, 4.5 \mathrm{~h}$ in chloroform at $20^{\circ} \mathrm{C}, 4.5 \mathrm{~h}$ in molten paraffin wax at $58^{\circ} \mathrm{C}$. Four micron sections from all samples were subjected to the following three "standard" digestion techniques:

$10.1 \%$ trypsin $(\mathrm{BDH}-39041)$ in $0.1 \%$ calcium chloride $\mathrm{pH} 7.8$ for $20 \mathrm{~min}$ at $37^{\circ} \mathrm{C}^{16}{ }^{17}$

$20.05 \%$ protease type VII (Sigma-P-5255) in phosphate buffered saline pH 7.3 (PBS) for 20 min at $37^{\circ} \mathrm{C}^{18}$

$30.4 \%$ pepsin (Sigma-P-7012) in $0.01 \mathrm{NHCl}$ for $120 \mathrm{~min}$ at $37^{\circ} \mathrm{C}^{13}$

These, together with an undigested set of sections, were immunostained for laminin and fibronectin using the indirect immunoperoxidase technique as previously described. ${ }^{18}$ One set of sections was stained after exposure to normal swine serum diluted 1/5 with PBS for $10 \mathrm{~min}$ before application of the first antibody. In another set this step was omitted.

Further four micron sections were then prepared from the $24 \mathrm{~h}$ formol saline fixed sample and subjected to the following digestion procedure variations:

1 Trypsin incubation for $20,30,40$, and $60 \mathrm{~min}$ at $37^{\circ} \mathrm{C}$ at concentrations of $0.2 \%, 0.1 \%$, and $0.05 \%$ in $0.1 \%$ calcium chloride $\mathrm{pH} 7 \cdot 8$

2 Protease type VII incubation for 10, 15, 20, and $30 \mathrm{~min}$ at $37^{\circ} \mathrm{C}$ at $0.05 \%, 0.025 \%$, and $0.0125 \%$ in PBS pH $7 \cdot 3$

3 Pepsin incubation for 30,60, 90, and $120 \mathrm{~min}$ at $37^{\circ} \mathrm{C}$ at concentrations of $0.6 \%, 0.4 \%$, and $0.2 \%$ in $0.01 \mathrm{NHCl}$.

Immunostaining for laminin and fibronectin was then performed as before.

Antibodies to fibronectin (A245) and peroxidase conjugated rabbit immunoglobulin (P217) were obtained from Dakopatts, Mercia Brocades Ltd, and antibodies to laminin (BRL 62655A) obtained from Bethesda Research Laboratories. All were diluted to $1 / 50$ in PBS $\mathrm{pH} 7 \cdot 3$ for use.

Throughout the study negative controls were used by substituting the primary antibody with PBS $\mathrm{pH}$ $7 \cdot 3$ or with non-immune rabbit IgG.

Fresh frozen breast tissue, both benign and malignant, was also collected and stained by the indirect immunofluorescence technique for fibronectin and laminin to confirm the expected distribution of these proteins.

\section{Results}

The results are summarised in Tables $1-4$. Staining intensity was subjectively graded - to +++ .

EFFECTS OF FIXATION

$10 \%$ formol saline

Fixation in $10 \%$ formol saline for 12,24 , or $48 \mathrm{~h}$

Table 1 Staining for laminin in variably fixed tissue

\begin{tabular}{|c|c|c|c|c|c|}
\hline Fixative & $\begin{array}{l}\text { Fixation } \\
\text { time } \\
\text { (hours) }\end{array}$ & Undigested & Trypsin & Protease & Pepsin \\
\hline $\begin{array}{c}\text { Formol } \\
\text { saline }\end{array}$ & $\begin{array}{l}12 \\
24 \\
48\end{array}$ & $\begin{array}{c}(+) \\
- \\
-\end{array}$ & $\begin{array}{l}- \\
-\end{array}$ & $\begin{array}{l}+++ \\
+++ \\
+++\end{array}$ & $\begin{array}{l}+++ \\
+++ \\
+++\end{array}$ \\
\hline $\begin{array}{c}\text { Formol } \\
\text { acetic } \\
\text { acid }\end{array}$ & $\begin{array}{l}12 \\
24 \\
48\end{array}$ & $\begin{array}{l}- \\
- \\
-\end{array}$ & $\begin{array}{l}- \\
- \\
-\end{array}$ & $\begin{array}{l}+++ \\
+++ \\
+++\end{array}$ & $\begin{array}{l}+++ \\
++t \\
++t\end{array}$ \\
\hline $\begin{array}{l}\text { Formol } \\
\text { sublimate }\end{array}$ & $\begin{array}{l}12 \\
24 \\
48\end{array}$ & - & $\begin{array}{l}- \\
-\end{array}$ & $\begin{array}{l}+ \\
- \\
-\end{array}$ & $\begin{array}{c}+++ \\
++ \\
(+)\end{array}$ \\
\hline $\begin{array}{l}\text { Ethanol } \\
\text { acetic } \\
\text { acid }\end{array}$ & $\begin{array}{l}12 \\
24 \\
48\end{array}$ & $\begin{array}{l}- \\
-\end{array}$ & $\begin{array}{l}t \\
t+ \\
t+\end{array}$ & $\begin{array}{l}+t+ \\
++t \\
+t+\end{array}$ & $\begin{array}{l}+++ \\
+++ \\
+++\end{array}$ \\
\hline
\end{tabular}


Table 2 Staining for fibronectin in variably fixed tissue

\begin{tabular}{clllll}
\hline Fixative & $\begin{array}{l}\text { Fixation } \\
\text { time } \\
\text { (hours) }\end{array}$ & Undigested & Trypsin & Protease & Pepsin \\
\hline Formol & 12 & - & - & +++ & +++ \\
saline & 24 & - & + & +++ & ++ \\
Formol & 48 & - & + & +++ & + \\
acetic & 12 & - & + & - & - \\
acid & 24 & - & ++ & $(+)$ & $(+)$ \\
Formol & 12 & - & + & - & - \\
sublimate & 24 & - & - & + & ++ \\
Ethanol & 48 & - & - & + & ++ \\
acetic & 12 & - & - & - & + \\
acid & 24 & - & - & - & - \\
\hline & 48 & - & - & - & - \\
\hline
\end{tabular}

Table 3 Staining for laminin in variably digested formalin fixed tissue

\begin{tabular}{lclll}
\hline Enzyme & $\begin{array}{l}\text { Digestion } \\
\text { time } \\
\text { (mins) }\end{array}$ & \multicolumn{3}{l}{ Enzyme concentration } \\
\cline { 2 - 5 } & $0.05 \%$ & $0.025 \%$ & $0.0125 \%$ \\
\hline $\begin{array}{llll}\text { Protease in } \\
\text { PBS pH 7.3 }\end{array}$ & 10 & +++ & ++ & + \\
& 20 & +++ & ++ & ++ \\
& 30 & +++ & ++ & ++ \\
& & +++ & +++ & +++ \\
\hline & & $0.2 \%$ & $0.1 \%$ & $0.05 \%$ \\
Trypsin in & 20 & - & - & - \\
$0.1 \% \mathrm{CaCl}$ & 30 & - & - & - \\
pH 7.8 & 40 & - & - & - \\
& 60 & - & - & - \\
\hline & & $0.6 \%$ & $0.4 \%$ & $0.2 \%$ \\
Pepsin in & 30 & $+++(+)$ & $++(+)$ & $++(+)$ \\
$0.01 \mathrm{~N} \mathrm{HCl}$ & 60 & +++ & +++ & +++ \\
& 90 & +++ & +++ & +++ \\
& 120 & +++ & +++ & +++ \\
\hline
\end{tabular}

Table 4 Staining for fibronectin in variably digested formalin fixed tissue

\begin{tabular}{lclll}
\hline Enzyme & $\begin{array}{l}\text { Digestion } \\
\text { time } \\
\text { (mins) }\end{array}$ & \multicolumn{3}{l}{ Enzyme concentration } \\
\cline { 2 - 5 } & $0.05 \%$ & $0.025 \%$ & $0.0125 \%$ \\
\hline $\begin{array}{llll}\text { Protease in } \\
\text { PBS pH 7.3 }\end{array}$ & 10 & +++ & +++ & +++ \\
& 20 & +++ & +++ & +++ \\
& 30 & +++ & +++ & +++ \\
& & +++ & +++ & +++ \\
\hline & & $0.2 \%$ & $0.1 \%$ & $0.05 \%$ \\
Trypsin in & 20 & + & + & + \\
$0.1 \% \mathrm{CaCl}_{2}$ & 30 & + & + & + \\
pH 7.8 & 40 & ++ & + & + \\
& 60 & ++ & ++ & ++ \\
\hline & & $0.6 \%$ & $0.4 \%$ & $0.2 \%$ \\
Pepsin in & 30 & ++ & ++ & ++ \\
$0.01 \mathrm{~N} \mathrm{HCl}$ & 60 & ++ & ++ & + \\
& 90 & + & + & + \\
& 120 & + & + & + \\
\hline
\end{tabular}

enabled optimal staining for both fibronectin and laminin after protease digestion (Figs. 1 and 2). Pepsin digestion was equally satisfactory for laminin demonstration but was slightly less reliable for fibronectin, although excellent results were sometimes achieved.

\section{Formol acetic acid}

Fixation in formol acetic acid allowed good immunohistochemical staining for laminin, but only after protease or pepsin digestion. Satisfactory staining for fibronectin was not obtained after any of the standard digestion procedures.

\section{Formol sublimate}

Fixation in formol sublimate produced less than optimal results for both proteins. Laminin was shown only after pepsin digestion and scarcely at all if fixation had been prolonged.

\section{Ethanol acetic acid at $4^{\circ} \mathrm{C}$}

Ethanol acetic acid at $4^{\circ} \mathrm{C}$ was an excellent fixative for demonstration of laminin when combined with protease or pepsin digestion. Trypsin also revealed laminin, although slightly less well. It proved completely ineffective for fibronectin, although a curious cytoplasmic staining was sometimes seen. This was judged to be artefactual.

None of the fixatives enabled positive staining for laminin or fibronectin in undigested paraffin embedded tissues. Since the results with $10 \%$ formol saline were as good as if not better than any other fixative tested and since this is the most commonly used routine fixative, the next part of the investigation was confined to tissue which had been fixed in formalin for $24 \mathrm{~h}$.

\section{VARIED DIGESTION PROCEDURES}

Trypsin used at concentrations of $0.05 \%-0.2 \%$ for 20-60 min did not successfully "unmask" laminin, while staining for fibronectin was weak and incomplete.

Protease used at a concentration of $0.0125 \%$ with a slight increase in incubation time (from 20 to 30 min) produced results equivalent to those produced by the "standard" procedure $(0.05 \%$ protease for $20 \mathrm{~min}$ ).

Pepsin could be successfully used at a concentration of $0.2 \%$ for 60 min rather than the "standard" $0.4 \%$ for $120 \mathrm{~min}$. Results with this enzyme were less reproducible for demonstration of fibronectin than for laminin.

\section{NORMAL SWINE SERUM}

Use of normal swine serum before application of the first antibody diminished background staining, par- 

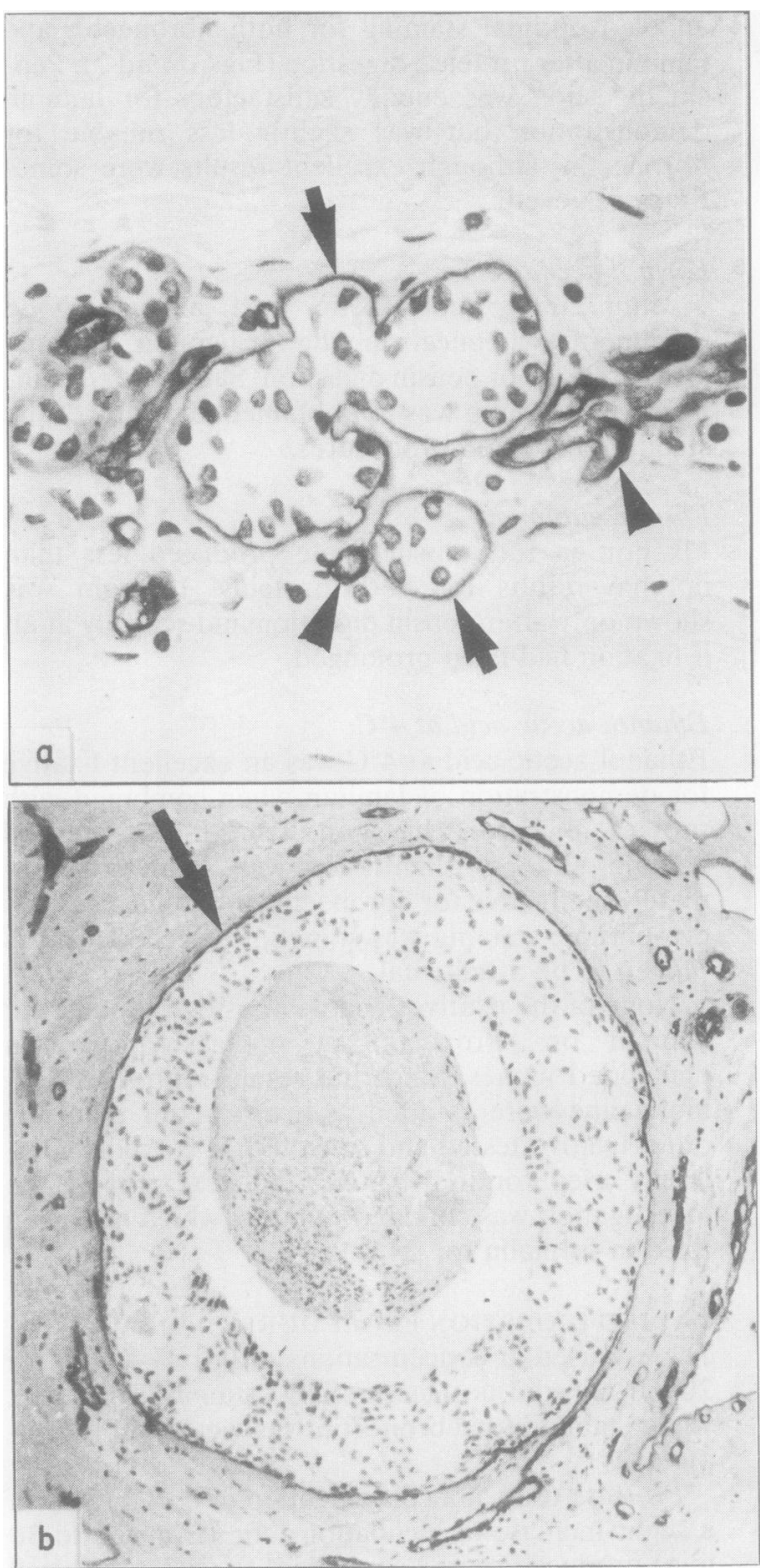

ticularly in preparations stained for laminin. There was no evidence that it produced false positive or enhanced background staining for fibronectin.

\section{CONTROLS}

All control sections were negative.

The distribution of laminin and fibronectin shown by immunofluorescent staining of frozen tissue was identical with that seen in positively stained paraffin
Fig. 1(a) Laminin in epithelial basement membranes (arrows) and capillary basement membranes (arrowheads) of a normal breast lobule. Cell nuclei are counterstained with haematoxylin. Indirect immunoperoxidase staining of protease digested, formalin fixed, paraffin embedded tissue $\times 200$.

Fig. 1(b) Ductal carcinoma of breast showing positive staining for laminin in ductal (arrow) and capillary basement membranes. Carcinoma cell nuclei are counterstained with haematoxylin but cytoplasm is negative. Indirect immunoperoxidase, protease digested, formalin fixed, paraffin embedded tissue $\times 125$. embedded tissue. Laminin was present in epithelial $\underset{\omega}{N}$ and endothelial basement membranes (Fig. 1) and around smcoth muscle cells and nerve fibres. Now intracytoplasmic laminin was shown. Fibronectin had a similar distribution (Fig. 2) but was also pres- ? ent in varying amounts in interstitial connective tis- 0 sue. In carcinoma laminin staining was discontinuous or absent from peripheries of tumour cell

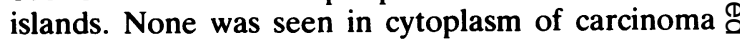
cells. Stromal fibronectin was increased. 

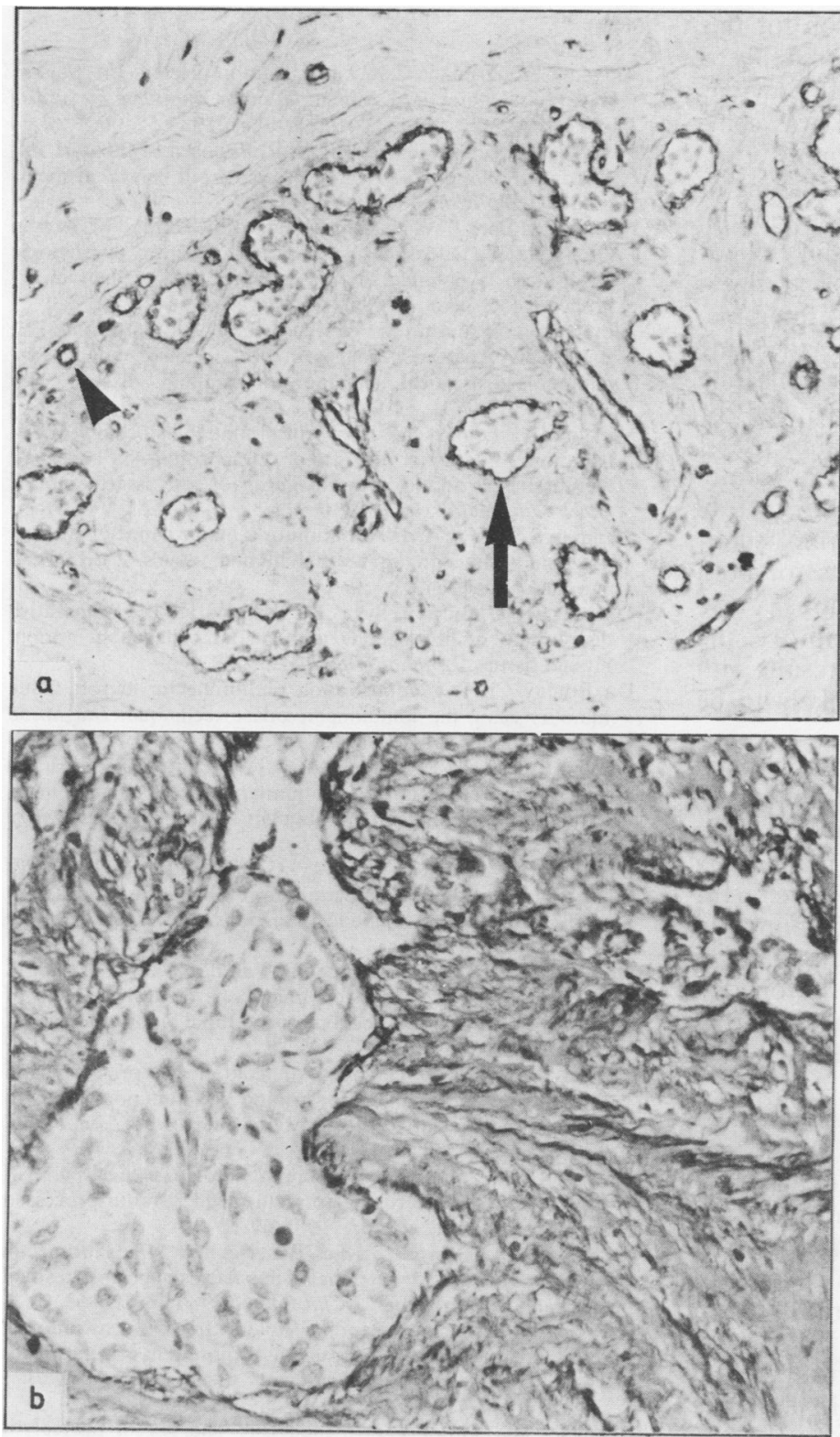

Fig. 2(a) Fibronectin in epithelial (arrow) and capillary (arrowhead) basement membranes of a normal breast lobule. Cell nuclei are counterstained with haematoxylin. Indirect immunoperoxidase staining of protease digested, formalin fuxed, paraffin embedded tissue $\times 125$.

Fig. 2(b) Increased fibronectin in stroma of infiltrating ductal carcinoma. Indirect immunoperoxidase/haematoxylin staining of protease digested, formalin fixed, paraffin embedded tissue $\times 200$.

\section{Discussion}

None of the fixatives tested enabled immunohistochemical staining of paraffin embedded tissues for fibronectin and laminin to be achieved without enzymatic digestion. Formol acetic acid and formol sublimate have been reported to allow staining of undigested tissue sections for cytoplasmic immunoglobulins, ${ }^{\prime \prime} 12$ but the efficacy of different techniques is clearly dependent on the nature and site of the antigens under investigation. Fibronectin and laminin shown in the present study were predominantly extracellular. The indirect peroxidase as opposed to the peroxidase-antiperoxidase method was used, but in our experience both techniques produce equivalent results with appropriate adjustment of primary antibody titres. ${ }^{18}$ The intracytoplasmic staining for laminin noted by Albrechtson et $\mathrm{al}^{4}$ in undigested ethanol acetic acid fixed tissue was not found after any method of fixation, nor on immunofluorescent 
staining of fresh frozen tissue. The reason for this discrepancy is not apparent, but one possibility is different antibody specificities. Contrary to previous observations, ${ }^{9}$ ethanol acetic acid at $4^{\circ} \mathrm{C}$ was completely unsatisfactory for fibronectin staining.

This study has confirmed that optimal staining of both fibronectin and basement membrane laminin can be achieved with formalin fixed paraffin embedded material after protease or pepsin digestion, ${ }^{101314}$ although protease was found preferable. With this enzyme the staining intensity was the same whether the tissue had been fixed in formol saline for 12,24 , or $48 \mathrm{~h}$-that is, the normal range for routine fixation. No advantage was gained by use of the other fixatives tested; on the contrary formol acetic acid and ethanol acetic acid were satisfactory only for laminin demonstration and formol sublimate produced less than optimal results for both proteins using standard digestion procedures. Varying the digestion techniques might improve the results with these fixatives, but since the results with digested formalin fixed tissue were unlikely to be bettered this was not pursued.

Trypsin was completely ineffective for laminin demonstration in formalin fixed tissue and only partially effective for fibronectin demonstration. Fibronectin in blood vessel walls was shown more easily than that in epithelial basement membranes. Inefficacy of trypsin for fibronectin staining in formalin fixed tissue has been noted previously, ${ }^{9}$ although du Boulay used this method for a study on fibronectin distribution in soft tissue tumours. ${ }^{8}$ It is possible that the commercial "brand" of trypsin used may affect the results.

We found that both protease and pepsin could be used at lower concentrations than in the "standard" recommended procedures. Since neither of these reagents is cheap, this may prove important if they are to be used regularly in routine laboratory diagnosis. It may be possible to reduce the concentrations still lower than those described here. A recent report has recommended using pepsin at $0.025 \%$ for $30-45 \mathrm{~min} .{ }^{10}$ This was found preferable to the usual $0.4 \%$ pepsin for $1-2 \mathrm{~h}$, which was said to make fibronectin localisation difficult due to overdigestion. In a preliminary experiment we have also found these lower pepsin concentrations effective, although we have not found overdigestion to be a problem with the "standard" pepsin or protease methods.

Our results indicate that the method of choice for routine immunohistochemical demonstration of both fibronectin and laminin in paraffin embedded material is protease digestion of tissue which has been fixed in formol saline.

We thank Miss Tina Chisnall for typing the manuscript.

\section{References}

' Akiyama SK, Yamada KM. Fibronectin in disease. In: Wagner BM, Fleischmajor R, Kaufman N, eds. Connective tissue diseases. Baltimore: Williams and Wilkins, 1983:55-96.

${ }^{2}$ Timpl R, Rohde H, Gehron-Robey P, Rennard SI, Foidart JM, Martin GR. Laminin-A glycoprotein from basement membranes. J Biol Chem 1979;254:9933-7.

${ }^{3}$ Foidart JM, Bere EW, Yaar M, Rennard SI, Gullino M, Martin GR, Katz SI. Distribution and immunoelectron microscopic localisation of laminin, a non-collagenous basement membrane glycoprotein. Lab Invest 1980;42:336-42.

4 Albrechtson R, Nielson M, Wewer U, Engavall E, Ruoslahti E. $\vec{\circ}$ Basement membrane changes in breast cancer detected by immunohistochemical staining for laminin. Cancer Res 1981;41:5076-81.

${ }^{5}$ Miettinen M, Foidart JM, Ekblom P. Immunohistochemical dis- $\overparen{\Omega}$ tribution of laminin, the major glycoprotein of basement membranes as an aid in the diagnosis of soft tissue tumours. W Am J Clin Pathol 1983;79:306-11.

- Stenman S, Vaheri A. Distribution of a major connective tissue protein, fibronectin, in normal human tissues. J Exp Med 1978; 147:1054-64.

' D'Ardenne AJ, Burns J, Sykes BC, Kirkpatrick P. Comparative distribution of fibronectin and type III collagen in normal human tissues. J Pathol 1983;141:55-69.

${ }^{8} \mathrm{Du}$ Boulay CEH. Demonstration of fibronectin in soft tissue tumours using the immunoperoxidase technique. Diagnostic Histopathology 1982;5:283-9.

${ }^{9}$ Holund B, Clausen PP, Clemmenson I. The influence of fixation and tissue preparation on the immunohistochemical demonstration of fibronectin in human tissue. Histochemistry 1981;72:291-9.

${ }^{10}$ Szendroi M, Labat-Robert J, Godeau G, Robert AM. Immunohistochemical detection of fibronectin using different fixatives in paraffin embedded sections. Pathologie Biologie 응 1983;31:631-6.

" Bosman FT, Lindeman J, Kuiper G, Van der Wal A, Kreunig J. The influence of fixation on immunoperoxidase staining of plasma cells in paraffin sections of intestinal biopsy specimens. Histochemistry 1977;53:57-62.

12 Curran RC, Gregory J. Effects of fixation and processing on immunohistochemical demonstration of immunoglobulin in paraffin sections of tonsil and bone marrow. J Clin Pathol $\overparen{ }$ 1980;33:1047-57.

${ }^{13}$ Burns J, Dixon AJ, Woods JC. Immunoperoxidase localisation of fibronectin in glomeruli of formalin fixed paraffin processed renal tissue. Histochemistry 1980;67:73-8.

${ }^{14}$ D' Ardenne AJ, Burns J, Sykes BC, Bennett MK. Fibronectin and type III collagen in epithelial neoplasms of gastrointestinal $O$ tract and salivary gland. J Clin Pathol 1983;36:756-63.

is Ekblom P, Miettinen M, Rapola J, Foidart JM. Demonstration of $D$ laminin, a basement membrane glycoprotein in routinely processed formalin fixed human tissues. Histochemistry 1982;75:301-7.

${ }^{16}$ Mepham BL, Frater W, Mitchell BC. The use of proteolytic $N$ enzymes to improve immunoglobulin staining by the PAP
technique. Histochem $J$ 1979;11:345-57.

${ }^{17}$ Curran RC, Gregory J. The unmasking of antigens in paraffin sections of tissue. Experientia 1977;33:1400-1.

${ }^{18}$ Sinclair RA, Burns J, Dunnill MS. Immunoperoxidase staining of formalin fixed paraffin embedded, human renal biopsies with a $\mathbb{E}$ comparison of peroxidase-anti-peroxidase (PAP) and indirect? methods. J Clin Pathol 1981;34:859-65.

Requests for reprints to: Mr P Kirkpatrick, Nuffield Department of Pathology, John Radcliffe Hospital, Level 1, Headington, Oxford OX3 9DU, England. 